\title{
UMA POSSIBILIDADE DE INTERLOCUÇÃO ENTRE ARQUIVOLOGIA, BIBLIOTECONOMIA, MUSEOLOGIA E CIÊNCIA DA INFORMAÇÃO
}

\author{
Daniele Galvão Pestana Nogueira' \\ Universidade de Brasília
}

\begin{abstract}
Os investigadores das áreas de Arquivologia, Biblioteconomia e Museologia encontram pontos de correspondência entre essas disciplinas, com o cuidado de não valorizar um modelo em detrimento do outro. O livro Arquivologia, Biblioteconomia, Museologia e Ciência da Informação: o diálogo possível, do professor Carlos Alberto Ávila, editado em 2014 pela Briquet de Lemos, traz mais uma área do conhecimento para o debate: a Ciência da Informação.
\end{abstract}

Oswaldo Francisco de Almeida Júnior, que escreveu o prefácio do livro destacou que:

Os objetos ou os núcleos do objeto não impedem a relação.Ao contrário, exigem a troca, o diálogo. As áreas de interesse do livro precisam uma das outras. A existência isolada pode até ser possível, mas acarretando empobrecimento teórico e prático; um olhar apenas para o próprio âmago, alijando-se do mundo, dos homens e das outras ciências; um não pertencimento ao universo do conhecimento humano.(ARAÚJO, 20I4)

Almeida Júnior ainda relata que o encontro da Arquivologia, Biblioteconomia e Museologia pode ser definido com base na análise de suas transformações, como fundamento para as teorias epistemológicas implícitas em cada uma. Mas quando se trata da ligação destas com a Ciência da Informação, é percebido que esses encontros aconteceram em ritmos diferentes.

Araújo relata no livro que esses encontros com a Ciência da Informação ocorreram primeiramente com a Biblioteconomia, seguida pela arquivística, e por último com a Museologia. No caso específico da Biblioteconomia, a sua relação com a Ciência da Informação é mais estreita do que com os outros campos, tanto no Brasil como no exterior, em razão da própria constituição desses campos, do compartilhamento de seu papel social e da preocupação dos registros gráficos. A proximidade da Museologia com a Ciência da Informação, no país, é atípica, visto que na literatura internacional essa relação quase não aparece. Essa relação foi oportunizada por diversos fatores como: vínculos institucionais, políticas públicas, ações acadêmicas e estudos preliminares. A ausência de cursos de pós-graduação stricto sensu em Museologia levou estudiosos e pesquisadores a desenvolverem suas pesquisas na Ciência da Informação. Tal fenômeno também foi encontrado no campo da Arquivologia, tendo sido realizados um número considerável de pesquisas de mestrado e doutorado na área da Ciência da Informação.

I Mestre em Ciência da Informação PPGCinf/ UnB. Museóloga do Tribunal de Contas da União. 
A riqueza do conteúdo apresentado pelo autor se dá pela sua formação e experiência acadêmica. Carlos Alberto Ávila Araújo possui doutorado em Ciência da Informação pela Universidade Federal de Minas Gerais-UGMG (2005) e pós-doutorado pela Faculdade de Letras da Universidade do Porto (20II). Atualmente, atua como professor da Escola de Ciência da Informação da Universidade Federal de Minas Gerais-UFMG.

Araújo possui um percurso acadêmico entre o jornalismo e a comunicação social, e hoje se debruça sobre a epistemologia da Ciência da Informação e para a articulação desta com a Arquivologia, Biblioteconomia e Museologia.

$\mathrm{Na}$ apresentação do livro, o autor nos contextualiza para o fato que as ideias expostas constituem a consolidação, com alterações de algumas propostas apresentadas em diversos artigos publicados em revistas especializadas e capítulos de livros. Tais argumentos e opiniões tiveram como ponto de partida quando Araújo, como professor da Escola de Ciência da Informação da UFMG, fez parte da Comissão de criação do curso de graduação em Arquivologia e de Museologia, em 2008. Neste momento foi percebido a necessidade de fundamentação teórica para propor e justificar o diálogo e a cooperação desses novos cursos entre si e com as áreas da biblioteconomia e a Ciência da Informação.

O objetivo do livro aqui apresentado é proporcionar uma leitura sobre essas áreas do conhecimento (Arquivologia, Biblioteconomia, Museologia e Ciência da Informação) e oferecer uma proposta de diálogo, com a ideia de que independente do objeto de cada ciência pode haver interlocução entre elas, revelando que não há barreiras intransponíveis. $O$ autor nos oferece uma leitura sobre essas áreas, trazendo questionamentos, apresentando suas incompatibilidades e sugere interação entre elas. $O$ livro é uma proposta de aproximação entre as áreas.

Araújo estruturou o livro em três capítulos. Nos dois primeiros, a Arquivologia, Biblioteconomia, Museologia e Ciência da Informação são abordadas nos seus aspectos históricos e síntese das correntes.

No primeiro capítulo, especificamente, é apresentado algumas das reflexões científicas em arquivologia, biblioteconomia e museologia que foram desenvolvidas ao longo do século $X X$, destacando traços históricos e teóricos comuns e percurso para a consolidação de cada área. $\bigcirc$ texto revela vários pontos e aspectos comuns entre as três áreas, tendo o objeto ou as técnicas de tratamento e a relação do ser humano com a realidade medida pelas intervenções produzidas por essas áreas. Para Araújo, a existência de arquivos, bibliotecas e museus conduziu a criação de uma série de procedimentos e métodos, em virtude da necessidade de lidar com seus acervos. A preocupação comum dessas instituições, coleta, armazenamento, disseminação da informação, nos mais variados suportes e formatos tem favorecido uma aproximação entre esses campos. Uma nova configuração dessas instituições tem favorecido ao diálogo entre elas e a formação de equipes interdisciplinares em arquivos que pode armazenar documentos de biblioteca e objetos e documentos de museu, ou o museu com uma biblioteca e um arquivo, ou o mesmo pode se dar em uma biblioteca.

No segundo capítulo, o autor traz para o diálogo a Ciência da Informação. Apresenta sua trajetória que por meio de contribuições desenvolvidas em diferentes subáreas e contextos temos um conceito amplo de informação que contempla suas dimensões físicas, cognitiva e intersubjetiva, considerando as várias maneiras por meio das quais algo se torna informação, isto é, é "in-formado”, no contexto da ação humana. 
As diferenças entre as quatro áreas apresentadas nos dois primeiros capítulos são apontadas no último capítulo estabelecendo um diálogo possível, $A$ proposta de aproximação entre as áreas. Araújo resgata a ideia de "olhar informacional", voltado para ação humana de "in-formar" (dar forma, existência material, a um pensamento ou ideia) e "se in-formar" (utilizar os registros materiais do conhecimento para construir suas ideias e pensamentos) e faz uma conexão ou traça um diálogo com as áreas apresentadas nos capítulo anterior, as áreas de Biblioteconomia, Arquivologia e Museologia que seriam, usando a linha argumentativa de Antônio Malheiro da Silva, epifenômenos, isto é, manifestações, visíveis de um fenômeno maior e mais amplo: a informação. (ARAÚJO, 20 I4, I55)

Araújo (20I4, I57) se utiliza das ideias de Geornot Wersing, a

informação, objeto de estudo da Ciência da Informação, pode ser compreendido e estuda por meio do estudo de outros fenômenos, estes sim, com existência concreta e material, na esfera da realidade humana

e também compartilhando com a perspectiva de Shera (ARAÚJO, 2014, I56), estudar bibliotecas, arquivo e museu e documento, antes de tudo estudar determinada realidade social.

Araújo destaca a Information Science, que se consolidou nos anos de 1960, foi marcado pelo positivismo e tecnicismo, centrado nos aspectos físicos e operacionais dos fenômenos informacionais. Segundo o autor, nesse tempo não havia possibilidade de diálogo com a Arquivologia, Biblioteconomia e Museologia. Agora com a retomada de autores como Garfinkel e Shera por pesquisadores contemporâneos - Rafel Capurro, Bernd Frohmann, Miguel Ángel Rendón Rojas, Birger Hjorland, Ronald E. Day, Marcia Battes, entre outros (ARAÚJO, 20 I4, I 57) oferece um cenário estimulante para interlocução e fertilização mutua.

O autor evoca uma das características, que para ele faz partes das 4 áreas que ele apresenta nos capítulos anteriores: o pertencimento ao terreno das $\mathrm{Ci}$ ências Humanas e Sociais. Para o autor, pensar em informação não significa descartar a função de salvaguarda do patrimônio promovido pelo arquivos, bibliotecas e museus, é pensar nela e inseri-la como uma das funções em meio a outras, na dinâmica de discussões sobre a dimensão informacional. (ARAÚJO, 20 I4, I 58, 159). Estudar a dimensão informacional nas instituições arquivísticas, biblioteconômicas e museológicas, com suas técnicas, seus acervos, seus profissionais que os constituiu é abrir a possibilidade de um campo de reflexão amplo e, portanto, favorável à aproximação, ao diálogo. Os conceitos de instituição, memória, documento, informação e interdisciplinaridade, guardam uma estreita relação com os campos apresentados. $O$ que possibilita uma diluição das rígidas fronteiras disciplinares, trazendo benefícios teóricos e aplicações práticas mais ricas.

As tendências contemporâneas apresentadas, em cada uma das quatro áreas citadas no livro, e em especial no Brasil, a Arquivologia, Biblioteconomia e Museologia que compartilham do mesmo ambiente institucional nas faculdades ou escolas de Ciência da Informação, são fatores que promovem o diálogo entre todas essas áreas. Essas condições trazem espaço para reflexões científicas que ressaltam a dimensão informacional nas práticas arquivísticas, biblioteconômicas e museológicas por meio do olhar informacional da Ciência Informação. 


\section{Referência}

ARAÚJO, Carlos Alberto Ávila. Arquivologia, Biblioteconomia, Museologia e Ciência da Informação: o diálogo possível. Brasília: Briquet de Lemos, 2014.

Resenha recebida em setembro de 2015. Aprovada em outubro de 2015 